\title{
BMJ Global Health The urgent need for a global commitment to protect healthcare workers
}

To cite: Talisuna A, Yoti Z, Lee $\mathrm{C}$, et al. The urgent need for a global commitment to protect healthcare workers. BMJ Global Health 2020;5:e004077. doi:10.1136/ bmjgh-2020-004077

Handling editor Seye Abimbola

Received 28 September 2020 Accepted 29 September 2020

Check for updates

(C) Author(s) (or their employer(s)) 2020. Re-use permitted under CC BY-NC. No commercial re-use. See rights and permissions. Published by BMJ.

${ }^{1}$ Health Emergecy Programme, Organisation mondiale de la Sante pour Afrique, Brazzaville, Brazzaville, Congo ${ }^{2}$ WHE Programme, WHO, Brazzaville, Congo ${ }^{3}$ Health Emergecy Programme, WHO, Brazzaville, Congo

${ }^{4}$ Resolve to Save Lives, New York, NY, USA

${ }^{5}$ WHO Regional Office for Africa, Brazzaville, Congo

Correspondence to Dr Ambrose Talisuna; talisunaa@who.int
Health workers are essential for improved global health-but the COVID-19 pandemic is decimating them. Worse still, we don't know the true toll the virus is taking on healthcare workers. In Africa, where the healthcare workforce of many countries was already desperately thin, the WHO counted nearly 42000 sickened clinicians as of 9 September 2020, ${ }^{1}$ but the total number of infected surely outstrips that. And the pandemic is still unfolding: ongoing community transmission of the virus in many countries in Africa means far more casualties yet to come.

We lionise health workers when, upholding their professional ethics to care for the ill, they put their lives on the line-but we should not force them to choose between their own health and that of their patients. Instead of sacrificing them to suppress today's pandemic, we must better protect this essential workforce.

Health workers are at disproportionate risk of contracting COVID-19. In some countries, they initially made up more than one in five cases. ${ }^{2}$ In South Africa, the minister of health issued a statement on 13 August 2020 reporting that more than 27000 health workers had been infected, by far the largest number on the continent. ${ }^{3}$ This transparent act should be commended because we need to know the magnitude, further analyse and understand the root cause of the problem in order to put in place concrete solutions to protect our health workers.

When health workers are at risk, so are their patients. In recent epidemics, health workers have unwittingly infected patients and colleagues. ${ }^{4}$ Of even greater concern, when the population perceives health facilities as unsafe, they delay or forgo needed care, leading to preventable deaths from other causes. ${ }^{5}$ Disruptions caused by the pandemic could result in millions of preventable deaths. ${ }^{6}$

Infections and deaths alone do not capture the full toll the pandemic is taking on health workers. In addition to facing the risk of exposure to the
Summary box

Health workers are essential for improved globa health, but are at disproportionate risk of contracting COVID-19 as well as experiencing adverse mental health impacts.

- We must better protect this essential workforce, because when health workers are at risk, their patients and the entire health system are also at risk.

- All WHO Member States and donor organisations must take immediate and specific action to better protect this essential workforce.

- A comprehensive approach will be required that involves the full hierarchy of infection prevention controls as well as systematic collection of data on health worker infections.

pathogen, they work long hours under psychologically stressful conditions, and often return to fearful communities who may even subject them to discrimination and violence, and where they risk bringing infections home to their loved ones. A March 2020 survey of hospital staff in Wuhan, China, found high rates of reported distress $(71 \%)$, depression $(50 \%)$, anxiety $(45 \%)$ and insomnia $(34 \%){ }^{7}$

A recent report by the Partnership for Evidence-Based Response to COVID-19 (PERC) sheds further light on the situation. It documented 193 protests by health workers across Africa, most seeking fairer compensation or improved safety measures. ${ }^{8}$ But the scarcity of information about infections among health workers leaves us in the dark about whether they are contracting the disease in facilities devoted to treating COVID-19 patients, those meant to address other ailments, or in their communities. Indeed, health workers are part of the communities where they are working. To effectively protect health workers, we need much more detailed data.

This problem is not confined to low-income countries. As per Amnesty International, even 
some of the world's wealthiest countries have struggled to safeguard their doctors and nurses. ${ }^{9}$ In Italy, 176 health workers have died ${ }^{10}$ and 836 in the USA by 21 July $2020{ }^{11}$ Protecting health workers requires a comprehensive approach involving the full hierarchy of infection prevention controls, including source control (including increased telemedicine), engineering changes (such as partitions and improved ventilation), administrative systems (such as separate areas or times for certain patients) and personal protective equipment (PPE). ${ }^{12}$

A reduction of the health workforce exacerbates what is already a grave shortage: the WHO estimates that by 2030 the world will need an additional 18 million health workers; ${ }^{13}$ and since each generation of doctors and nurses depends on the mentorship of those preceding them, the loss of senior clinicians today affects the clinicians of tomorrow. Without health workers, there is no healthcare, so progress in beating COVID-19, and dreams of achieving universal health coverage, will be dashed if we don't alter this trajectory.

It doesn't have to be this way. Health workers are endangered when they do not receive training on infection prevention and control, and when the places they work run short of PPE and testing kits, run delays in returning test results or lack basic necessities such as running water.

WHO and its partners have worked hard to improve procurement mechanisms for much-needed medical supplies. Further, WHO is advocating for the mobilisation of resources to secure PPE supplies for countries and is conducting training of healthcare workers in infection prevention and control.

Many African countries have struggled to secure PPE for their health workers, partly because there are shortages of PPE on the international market. However, we have also become aware of instances of corruption and misuse of funds including for contracts for the procurement of PPE. Corruption, particularly in procurement of supplies that are required to protect life, is unacceptable.

We call on all WHO Member States and donors to take immediate and specific action to better protect this essential workforce. In particular, Member States must systematically collect data on health worker infections, their circumstances and their outcomes. They need to ensure their health facilities strengthen their own policies and protocols to protect the workforce from infection and from transmitting the virus back to other patients. ${ }^{14}$ And they must invest in measures that healthcare workers can use to protect themselves, including comprehensive infection prevention and control, prioritising them for access to PPE and ensuring appropriate working conditions.

This isn't the first epidemic to strike the healthcare workforce, and it won't be the last; but we must learn from our past failures and ensure a safer future. COVID-19 presents yet another opportunity-and urgent requirement-to strengthen protection of health workforce.

Twitter Thomas R Frieden @DrFrieden

Contributors Each of the listed authors meet the criteria for 'Authorship' in accordance with the ICMJE recommendations as outlined below: Substantial contributions to the conception or design of the work; AND Drafting the work or revising it critically for important intellectual content; AND Final approval of the version to be published; AND Agreement to be accountable for all aspects of the work in ensuring that questions related to the accuracy or integrity of any part of the work are appropriately investigated and resolved.

Funding The authors have not declared a specific grant for this research from any funding agency in the public, commercial or not-for-profit sectors.

Competing interests None declared.

Patient consent for publication Not required.

Provenance and peer review Not commissioned; internally peer reviewed.

Data availability statement All data relevant to the study are included in the article.

Open access This is an open access article distributed in accordance with the Creative Commons Attribution Non Commercial (CC BY-NC 4.0) license, which permits others to distribute, remix, adapt, build upon this work non-commercially, and license their derivative works on different terms, provided the original work is properly cited, appropriate credit is given, any changes made indicated, and the use is non-commercial. See: http://creativecommons.org/licenses/by-nc/4.0/.

\section{ORCID iDs}

Ambrose Talisuna http://orcid.org/0000-0001-6436-3415

Thomas R Frieden http://orcid.org/0000-0002-4759-2256

\section{REFERENCES}

1 World Health Organization, Regional Office for Africa. COVID-19 situation update for the who Africa region, external situation report 28, 2020. Available: https://apps.who.int/iris/bitstream/handle/10665/334234/ SITREP_COVID-19_WHOAFRO_20200909-eng.pdf [Accessed 25 Sept 2020].

2 Evans DK, Goldstein M, Popova A. The next wave of deaths from Ebola? the impact of health care worker mortality. world bank group, Africa region, 2015. Available: http://documents1.worldbank.org/curated/en/ 408701468189853698/pdf/WPS7344.pdf [Accessed 25 Sept 2020].

3 AS English. Over 27,000 health workers infected with Covid-19 in South Africa, 2020. Available: https://en.as.com/en/2020/08/14/latest news/ 1597361222_915673.html [Accessed 25 Sept 2020].

4 Frieden TR, Lee CT. Identifying and interrupting superspreading events implications for control of severe acute respiratory syndrome coronavirus 2. Emerg Infect Dis 2020;26:1059-66.

5 Wilkason C, Lee C, Sauer LM, et al. Assessing and reducing risk to healthcare workers in outbreaks. Health Secur 2020;18:205-11.

6 The Global Fund. Mitigating the impact of COVID-19 on countries affected by HIV, tuberculosis and malaria, 2020. Available: https://www. theglobalfund.org/media/9819/covid19_mitigatingimpact_report_en.pdf [Accessed 25 Sept 2020].

7 Lai J, Ma S, Wang Y, et al. Factors associated with mental health outcomes among health care workers exposed to coronavirus disease 2019. JAMA Netw Open 2020;3:e203976.

8 PERC. Partnership for evidence-based response to COVID-19 (PERC). brief on public health and social measures implementation in Africa, 1427 July 2020, 2020. Available: https://preventepidemics.org/wp-content/ uploads/2020/08/PERC_Brief-on-PHSM-Implementation-in-Africa_-1427-July-2020.pdf [Accessed 25 Sept 2020].

9 Amnesty International. Global: health workers silenced, exposed and attacked, 2020. Available: https://www.amnesty.org/en/latest/news/ 2020/07/health-workers-rights-covid-report [Accessed 25 Sept 2020].

10 FNOMCeO. List of doctors who died during the Covid-19 epidemic, 2020. Available: https://portale.fnomceo.it/elenco-dei-medici-caduti-nelcorso-dellepidemia-di-covid-19 [Accessed 25 Sept 2020].

11 KHN. Lost on the frontline, 2020. Available: https://khn.org/news/ lost-on-the-frontline-health-care-worker-death-toll-covid19coronavirus [Accessed 25 Sept 2020].

12 Dooley SW, Frieden TR. We must rigorously follow basic infection control procedures to protect our healthcare workers from SARS-CoV-2. Infect Control Hosp Epidemiol 2020:1-3.

13 Global Health Workforce Alliance, World Health Organization. A universal truth: no health without a workforce, 2013. Available: https://www.who. int/workforcealliance/knowledge/resources/hrhreport2013/en [Accessed 25 Sept 2020].

14 World Health Organization. Guidelines on core components of infection prevention and control programmes at the national and acute health care facility level, 2016. Available: https://www.who.int/infection-prevention/ publications/ipc-components-guidelines/en [Accessed 25 Sept 2020]. 